\title{
NOTE ON THE SECOND EDITION
}

This collection of original articles was first published in spring 2005 by the Wittgenstein Archives at the University of Bergen in the series Working Papers from the Wittgenstein Archives at the University of Bergen, no. 17 (see http://wab.aksis.uib.no/wab_workingpapers.page). For this edition, the collection has been expanded with an article by James Conant, and the introduction adjusted accordingly. The contributions by Marie McGinn and Hanjo Glock have been revised, and a very few corrections have been made to the other contributions.

We thank the Austrian Ludwig Wittgenstein Society for the possibility to publish this valuable collection in their Schriftenreihe.

Bergen, June 2006

Alois Pichler, Simo Säätelä

NOTE ON THE SECOND EDITION $\quad \mathbf{9}$ 
